\title{
MANAJEMEN MASJID NAMIRA LAMONGAN SERTA DAMPAKNYA TERHADAP JAMAAH MENURUT MAQASHID SYARIAH ${ }^{1}$
}

\author{
Nanda Nur Novadina \\ Departemen Ekonomi Syariah - Fakultas Ekonomi dan Bisnis - Universitas Airlangga \\ Email: nandanurnovadina@gmail.com \\ Irham Zaki \\ Departemen Ekonomi Syariah - Fakultas Ekonomi dan Bisnis - Universitas Airlangga \\ Email: irhamzaki@yahoo.com
}

\begin{abstract}
:
This research aimed to find out what the takmir's management of Namira mosque was and its impact on society based on maqashid Syariah perspective. It based on the phenomenon that happened in the research object. The research object was the Namira mosque, which is located in Jotosanur village, Lamongan. This research used a qualitative method with a descriptive approach. After interviewing, the results of the research were analyzed by using descriptive data analysis technique. The result of the research showed that how much the operational funds were that takmir of Namira mosque needed, and it was not very often that lack of funds was covered by the family foundation of Namira mosque. Then, the impact caused by the implementation of Rupiah zero-balance that the funds were used to donate to the activities taking place in the Namira mosque has been fulfilled based on maqashid Syariah.
\end{abstract}

Keywords: Infaq, Mosque, Welfare, Maqashid Syariah.

\section{PENDAHULUAN}

Dengan banyaknya penduduk yang menganut agama Islam maka Indonesia dinobatkan sebagai salah satu negara dengan penduduk Muslim terbesar di seluruh dunia (support.muslimpro.com: Februari, 2018). Pesatnya pertumbuhan penduduk yang beragama Islam maka akan menghasilkan potensi kevangan dari sumber filantropi islami yang tinggi. Beriringan dengan hal tersebut maka dana yang terkumpuldapat dimanfaatkan secara optimal, misal untuk pembangunan taman baca Al-Qur'an, pembiayaan sekolah bagi anak didik yang kurang mampu, bagi modal awal para pengusaha UMKM yang sebenarnya mempunyai skill yang mumpuni akan tetapi tidak memiliki cukup dana untuk memulai usahanya, serta membantu pembangunan infrastuktur pemerintah baik dalam skala makro maupun skala mikro.

Terdapat berbagai cara untuk memindahkan hak dari satu orang ke orang lain dalam hukum muamalah, salah satu caranya ialah dengan infak. Infak merupakan salah satu bentuk tindakan yang berperan ganda yakni sebagai suatu ibadah yang artinya dapat mendekatkan diri kepada Allah dan juga disisi lain dapat menolong orang yang membutuhkan bantuan. Sehingga infak dapat mempererat hubungan

\footnotetext{
${ }^{1}$ Jurnal ini merupakan bagian dari skripsi Nanda Nur Novadina, NIM: 041411 433023, yang diuji pada tanggal 15 Januari 2019.
} 
Novadina, et al/Jurnal Ekonomi Syariah Teori dan Terapan Vol. 6 No. 3 Maret 2019: 510-524; MANAJEMEN MASJID NAMIRA LAMONGAN SERTA DAMPAKNYA TERHADAP JAMAAH MENURUT MAQASHID SYARIAH

habluminallah dan juga habluminnaas secara bersamaan (al-Buny, 1991:31).

Dikutip dari salah satu situs berita suaramerdeka.com menyatakan bahwa potensi keuangan yang didapat melalui umat Islam dari infak masjid se Daerah Istimewa Yogyakarta sendiri sangatlah besar menurut Dewan Masjid Indonesia (DMI) Wilayah Daerah Istimewa Yogyakarta. Akan tetapi dana tersebut tidak termanfaatkan sama sekali, padahal jumlahnya mencapai Rp. 296 miliar pertahun menurut Ketua DMI DIY, Prof. Dr. Muhammad Thoriq, M.Ag.

$$
\text { Hal tersebut sangatlah }
$$

disayangkan apabila dana infaq sebesar itu seharusnya dapat dimanfaatkan seoptimal mungkin bagi pemberdayaan umat, dan dapat membawa dampak yang signifikan. Mengingat bahwa pertumbuhan umat Muslim sangatlah pesat. Dana tersebut dapat dimanfaatkan baik dalam hal pembiayaan modal awal para pengusaha UMKM, pembiayaan beasiswa anak berprestasi akan tetapi tidak memiliki dana yang cukup untuk meneruskan pendidikan, dan juga pembangunan taman belajar Al-Qur'an di sekitar masjid. Masjid bukan hanya sebuah bangunan yang digunakan untuk beribadah sebanyak lima kali dalam sehari, bukan hanya sebagai tempat untuk mengingat dosa kemudian memohon ampun kepada Allah, mensyukuri nikmat yang telah diberikan oleh Allahmasjid mempunyai nilai lebih didalamnya. Serta masjid merupakan poros peradaban umat
Islam pada masanya (Qardhawi, 2000:78). Masjid memiliki dua fungsi yang utama, yakni fungsi hablumminallah sekaligus hablumminannas. Kemaslahatan umat dapat ditingkatkan dengan optimal apabila dana di dalam masjid dapat dimanfaatkan semaksimal mungkin. Dana infaq yang terkumpul dalam masjid merupakan salah satu potensi dana yang sangat besar dari umat muslim. Apabila dana infaq dapat dialokasikan misalnya untuk mengundang penceramah yang kondang mislanya, maka akan banyak jamaah yang datang berkunjung untuk mendengarkan kajian tersebut dan dari hal tersebut dapat mendatangkan pendapatan tambahan sampingan untuk para pedagang yang notabene kebanyakan ialah masyarakat sekitar masjid itu sendiri, misalnya warung-warung pinggir jalan yang akan ramai kedatangan tamu, toko oleh-oleh khas kota tersebut dan juga tempat wisata yang lain dari kota tersebut.

$$
\text { Kemajuan sebuah masjid }
$$
tergantung pada masyarakat di sekitar masjid tersebut khususnya pengelola yang biasa disebut dengan takmir masjid. Setiap masjid pasti memiliki takmir atau pengurus yang merawat masjid serta memberikan jasa pelayanan kepada masyarakat yang ingin menyedekahkan sebagian dananya untuk diberikan kepada orang lain baik berupa infaq, sedekah, ataupun zakat. Semakin besar sebuah masjid semakin banyak pula jamaah masjid tersebut. Bisa jadi banyaknya jamaah suatu masjid akan 
Novadina, et al/Jurnal Ekonomi Syariah Teori dan Terapan Vol. 6 No. 3 Maret 2019: 510-524; MANAJEMEN MASJID NAMIRA LAMONGAN SERTA DAMPAKNYA TERHADAP JAMAAH MENURUT MAQASHID SYARIAH

mempengaruhi besarnya dana yang dikelola oleh pengurus masjid tersebut.

Apabila para takmir dapat mendayagunakan dana infaq yang didapat dari para jamaah seoptimal mungkin, maka akan banyak sekali pihakpihak yang terbantu. Para takmir masjid dapat membuat program kerja yang nantinya dapat membawa kesejahteraan bagi masyarakat sekitar baik secara langsung maupun tidak langsung. Melalui masjid pula, dana infaq yang ada dapat tersalurkan kepada yang berhak menerimanya. para takmir masjid diharapkan dapat memberikan dana infaq dari para jamaah sesuai dengan tepat sasaran.

Dengan tepat sasaran serta tepat guna para takmir masjid mendayagunakan dana infaq dengan menjalankan beberapa program yang nantinya dapat memancing roda perekonomian berputar dengan lancar sehingga nantinya peredaran harta bergerak lebih cepat. Hal tersebut dikarenakan kreatifnya para takmir masjid dalam mendayagunakan dana infaq masjid yang didapat dari para jamaah masjid.

Apabila dana infaq dapat dikembangkan sebaik mungkin, maka infaq mendapatkan perannya sebagai salah satu alat untuk pengembangan masyarakat dan juga dapat membentuk kemandirian masyarakat tersebut. Hal tersebut dapat terwujud dengan menggunakan dana infaq yang terkumpul dari para jamaah masjid.
Oleh karena itu, hal tersebut sangatlah disayangkan apabila pelvang yang besar ini diabaikan begitu saja. Mengingat begitu besarnya jumlah umat Muslim yang berada di negara ini dan juga potensi keuangan yang cukup besar yang didapat dari dana infaq masjid yang dapat memakmurkan ekonomi umat, setidaknya bagi lingkup jamaah masjid itu sendiri.

\section{LANDASAN TEORI}

Menurut Gus Arifin (169:2016) Infaq adalah salah satu bentuk pengeluaran yang jumlah tidak ditetapkan diawal dan berasal dari pemasukan pribadi kemudian dana yang terkumpul akan digunakan untuk kepentingan keluarga, kepentingan umat maupun untuk kepentingan sosial lainnya. Infaq berasal dari bahasa arab (أنفق - ينفق): mengeluarkan, membelanjakan (harta/vang). Menurut KBBI infaq berarti pemberian (sumbangan) harta dan sebagainya (selain zakat wajib) secara sukarela dan tanpa paksaan apapun untuk digunakan bagi kebaikan orang lain serta diharapkan dapat meningkatkan taraf hidup si penerima. Hal tersebut mengindikasikan bahwasanya infaq merupakan pengeluaran yang dikeluarkan secara sukarela dari seseorang kepada pihak-pihak yang lebih membutuhkan. Karena cakupannya yang luas dan juga tidak adanya aturan terhadap kepada siapa saja infaq tersebut harus diberikan maka si pemberi infaq dapat secara bebas memberikan infaq tersebut kepada siapapun yang dikehendakinya. 
Novadina, et al/Jurnal Ekonomi Syariah Teori dan Terapan Vol. 6 No. 3 Maret 2019: 510-524; MANAJEMEN MASJID NAMIRA LAMONGAN SERTA DAMPAKNYA TERHADAP JAMAAH MENURUT MAQASHID SYARIAH

Allah berfirman dalam Q.S AlBaqarah: 262

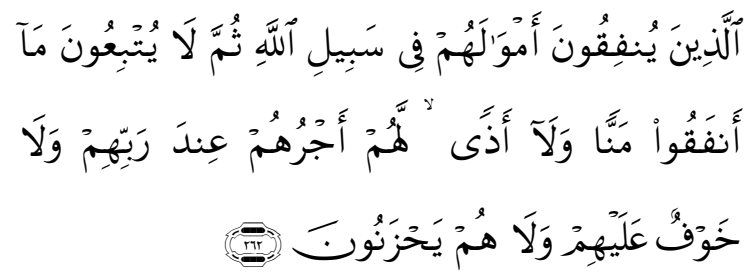
allażìna yunfiqụna amwālahum fĩ sabiillāhi summa lā yutbi'una mā anfaqu mannaw wa lā ażal lahum ajruhum 'inda rabbihim, wa lā khaufun 'alaihim wa lā hum yahzanụn

Artinya: "Orang yang menginfaqkan hartanya di jalan Allah, kemudian tidak mengiringi apa yang dia infaqkan itu dengan menyebut-nyebutnya dan menyakiti (perasaan penerima), mereka memperoleh pahala di sisi Tuhan mereka. Tidak ada rasa takut pada mereka dan mereka tidak bersedih hati."

Menurut Shihab (691:2009) Dalam surat tersebut dijelaskan bahwasanya apabila kita memberikan suatu pemberian dengan niat ikhlas dan juga pemberian tersebut dapat merigankan serta menyenangkan hati si penerima maka pahala merupakan balasan yang setimpal. Hal tersebut karena infaq dilakukan secara sukarela dan ikhlas tanpa pamrih untuk mendapatkan balasan apapun dari penerimanya, yang diharapkan hanyalah pahala dari Allah semata, serta para pemberi infaq juga tidak mengkhawatirkan bila hartanya akan habis suatu hari nanti, dikarenakan keyakinan bahwa Allah akan membalas lebih dari yang mereka infaqkan.Allah telah menetapkan hukum infaq dan telah menfirmankanya dalam beberapa ayat Al-Qur'an Q.S Al-Baqarah: 195

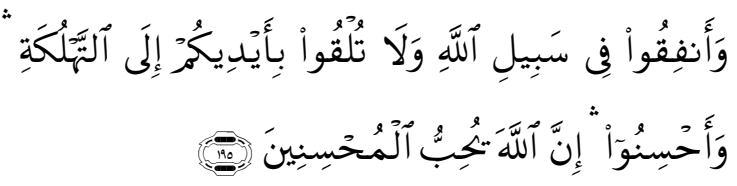

wa anfiqu fi sabilillāhi wa lā tulqu biaidikum ilat-tahlukati wa ahsinụ, innallāha yuhibbul-muhsinīn

Artinya: "Dan belanjakanlah (hartamu) di jalan Allah, dan janganlah kamu jatuhkan (diri sendiri) ke dalam kebinasaan dengan tangan sendiri, dan berbuat baiklah. Sungguh, Allah menyukai orang-orang yang berbuat baik."

Menurut tafsir Shihab (512:2009) kalimat (فِى سَيَيلِ الََّّ) fii sabiilillaahi/di jalan Allahpada firman-Nya: Dan belanjakanlah harta bendamu di jalan Allah, ayat ini memberi tahukan bahwasanya harta benda tersebut tidak akan menjadi harta yang produktif apabila tidak disalurkan di jalan Allah, akan tetapi apabila harta tersebut di salurkan kepada pihak - pihak yang membutuhkan maka harta benda tersebut akan dilipat gandakan serta mendapat penjagaan oleh Allah. Pada ayat ini juga dijelaskan apabila kita enggan untuk mengeluarkan harta kita untuk kebaikan umat Islam ataupun untuk berjuang di jalan Allah hal tersebut secara tidak langsung akan membawa kita ke dalam kebinasaan karena musuh yang akan kita lawan mempunyai persenjataan yang lengkap sehingga dapat mengalahkan kaum muslimin, dari kekalahan itu juga akan hilang nilai-nilai akidah yang sudah tertanam sejak dini pada kita, rasa percaya kepada Allah 
Novadina, et al/Jurnal Ekonomi Syariah Teori dan Terapan Vol. 6 No. 3 Maret 2019: 510-524; MANAJEMEN MASJID NAMIRA LAMONGAN SERTA DAMPAKNYA TERHADAP JAMAAH MENURUT MAQASHID SYARIAH

pun juga akan hilang serta ketenangan lahir dan batin pun akan hilang apabila kita menginfaqkan harta kita di jalan Allah sehingga harta tersebut tidak berkembang dan juga tidak berlipat ganda. Dengan banyaknya jumlah muslim yang tinggal di Indonesia ini, pastilah akan berbanding lurus dengan banyaknya jumlah masjid yang didirikan, karena masjid merupakan tempat para umat Muslim beribadah dan bersujud memohon ampun kepada Allah. Dengan banyaknya masjid yang ada maka akan mempermudah akses kaum muslim untuk beribadah baik kapanpun dan dimanapun.

Peran masjid di Indonesia masih berjalan sesuai dengan apa yang diajarkan oleh Rasulullah yakni sebagai tempat penyebaran dan pendidikan agama Islam. Akan tetapi dengan berjalannya zaman, maka peran masjidpun semakin bertambah luas, berikut ialah beberapa peran masjid (ICMI Orsat Cempaka Putih: 2004) :

1) Pusat kegiatan umat Islam, baik kegiatan sosial, pendidikan, politik, budaya, dakwah maupun kegiatan ekonomi.

Dengan adanya masjid, umat Islam dapat menggunakannya sebagai pusat segala kegiatan pengembangan, baik itu pengembangan bakat maupun pengembangan kerohanian. Jadi masjid memiliki fungsi sampingan yakni sebagai salah satu tempat berkumpul membicarakan permasalahan sosial yang sedang terjadi ditengah masyarakat sekarang ini dan mencoba mengambil jalan tengahnya yang masih sesuai dengan syariat Islam. Masjid juga biasanya dimanfaatkan untuk pengembangan ekonomi masyarakat sekitar masjid, karena biasanya para ta'mir mendirikan suatu Baitul Mal dan juga para ta'mir yang bertugas sebagai amil untuk mengumpulkan kemudian mendistribusikan zakat, infaq, serta sedekah yang diterima dari para jamaah serta masyarakat sekitar.

2) Masjid sebagai lambang kebesaran Islam.

Masjid dinilai sebagai lambang kebesaran Islam, karena masjid merupakan simbol bahwasanya umat Muslim hidupnya penuh dengan rasa tolong-menolong dan saling gotong royong antara umat yang satu dengan yang lainnya. Contohnya saja ialah masjid Demak yang merupakan salah satu masjid yang dinilai megah pada saat peradaban Islam di Pulau Jawa mulai berkembang dengan pesatnya. Kemudian juga masjid Quba yang pertama kali dibangun oleh umat Muslim pertama kali, masjid Quba pada saat itu hanyalah bangunan yang bermodalkan pelepah kurma dan tanah liat merupakan salah satu simbol kebesaran peradaban Islam.

3) Masjid sebagai pusat pengembangan IImu

$$
\text { Masjid dinilai dapat }
$$
mengembangkan perannya sebagai 
Novadina, et al/Jurnal Ekonomi Syariah Teori dan Terapan Vol. 6 No. 3 Maret 2019: 510-524; MANAJEMEN MASJID NAMIRA LAMONGAN SERTA DAMPAKNYA TERHADAP JAMAAH MENURUT MAQASHID SYARIAH

pusat pengembangan ilmu pengetahuan baik ilmu pengetahuan yang berkaitan dengan duniawi maupun ilmu pengetahuan yang berkaitan dengan hidup di hari akhir kelak. Banyak masjid di Indonesia ini yang telah dilengkapi dengan perpustakaan masjid, Taman Pendidikan Al-Qur'an (TPA) dan juga aula-aula yang dapat digunakan untuk mengadakan temu ilmiah. Masjid juga berperan sebagai penumbuh tingkat religiusitas masyarakat dengan cara para takmir masjid mengadakan kajian rutin baik mingguan maupun bulanan.

Dalam setiap unsur kehidupan, dibutuhkan kerangka yang runtut dan sistematis. Hal tersebut dibutuhkan agar manusia dalam menjalani kehidupannya runtut dan sesuai dengan kaidah-kaidah yang telah ditetapkan oleh Allah, baik secara langsung maupun melalui perantara yakni para nabi dan rasul melalui wahyu. Begitu pula dengan maqashid syariah. Apabila kita sebagai umat manusia tidak mampu menjaga maqashid syariah yang sudah runtut dan sistemastis, maka hidup kita akan tidak akan beraturan.

Fauzia dan Riyadi (2014:66-67) menyatakan untuk mencapai suatu kemaslahatan baik di dunia maupun di akhirat, para ulama menetapkan terdapat lima unsur pokok yang harus diperhatikan. Kelima unsur tadi bersumber dari Al-Qur'an dan merupakan tujuan dari hukum syari'ah (maqashid syariah). Apabila kelima unsur pokok tadi tidak dijaga secara baik, maka akan menimbulkan kerusakan baik di dunia maupun di akhirat kelak.

Secara rinci, Al-Syatibi membagi maqashid syariah menjadi dlaruriyat, hajiyah, dan tahsiniyah.

1. Dharuriyyat

Dharuriyyat merupakan dasar pokok dalam maqashid syariah. Apabila dharuriyyat tidak dapat dipenuhi, maka akan menyebabkan tidak sempurnanya maqashid syariah itu sendiri. Lain hal nya apabila hajiyyat dan tahsiniyyat yang tidak terpenuhi, maka dharuriyyat dapat menyokong dirinya sendiri. Jadi, tahsiniyyah dijaga untuk membantu menopang hajiyyat, dan hajiyyat dijaga untuk membantu menopang dharuriyyat.

Dharuriyyat dibagi menjadi lima poin utama yang dikenal dengan alkulliyat al-khamsah yaitu: (1) penjagaan terhadap agama (Hifz alDin); (2) penjagaan terhadap jiwa (Hifz al-Nafs); (3) penjagaan terhadap akal (Hifz al-'Aql); (4) penjagaan terhadap keturunan (Hifz al-Nasl); (5) penjagaan terhadap harta benda (Hifz al-Mal).

Apabila kelima hal tersebut terjaga dan dapat dipenuhi maka kesejahteraan suatu kehidupan akan terwujud baik di dunia maupun di akhirat kelak, atau dalam ekonomi Islam dikenal dengan istilah falah. Tercukupinya kebutuhan masyarakat akan memberikan dampak besar yang dikenal dengan maslahah, kelima hal tadi merupakan suatu kebutuhan dasar 
Novadina, et al/Jurnal Ekonomi Syariah Teori dan Terapan Vol. 6 No. 3 Maret 2019: 510-524; MANAJEMEN MASJID NAMIRA LAMONGAN SERTA DAMPAKNYA TERHADAP JAMAAH MENURUT MAQASHID SYARIAH

yang haruslah dipenuhi oleh masingmasing individu dalam masyarakat. Apabila salah satu dari lima elemen pokok tadi tidak terpenuhi maka kehidupan di dunia tidak akan berjalan dengan baik dan akan berdampak negatif.

Berdasarkan penjelasan tersebut dapat diketahui bahwa dlaruriyat merupakan instrumen yang paling penting serta krusial dalam maqashid syariah. Apabila kebutuhan dlaruriyat sendiri cacat dan tidak sempurna maka hal tersebut dapat mengganggu jalannya dalam mencapai maslahah, apabila dari hal primernya saja belum dapat dipenuhi maka kemaslahatan yang didamba-dambakan tidak akan tercapai, begitu juga sebaliknya apabila kebutuhan dlaruriyat telah tercapai secara lengkap dan sempurna maka tidak akan ada halangan untuk mencapai maslahah kedepannya.

2. Hajiyyah

Di tahapan kedua dari maqashid syari'ah ialah hajiyyat yang berarti "suatu pelengkap yang hadir untuk menghilangkan kesulitan yang nantinya dapat menyebabkan bahaya dan ancaman". Atau dapat dikatakan bahwa apabila hajiyyat dapat terpenuhi maka ia dapat menambah value kehidupan seseorang. Hajiyyat dapat menambah efisiensi, efektivitas dan value added (nilai tambah) bagi aktivitas manusia.
Hajiyyah merupakan kebutuhan yang gunanya ialah menunjang dalam melakukan suatu kegiatan. Contohnya dalam penjagaan terhadap agama untuk melakukan shalat maka baiknya dikerjakan di dalam masjid, maka kebutuhan dlaruriyyatnya ialah shalat dalam rangka memenuhi kebutuhan dlaruriyyat sedangkan dalam memenuhi kebutuhan hajiyyat maka shalat tersebut dilakukan dalam ruangan yang memadai, maka dari itu kebutuhan hajiyyatnya ialah melakukan shalat tersebut didalam masjid. Dengan adanya tambahan dari kebutuhan hajjiyat ini maka akan menambahkan value serta esensi dari shalat itu sendiri karena fungsi dasar dari kebutuhan hajiyyat ialah sebagai penunjang kehidupan manusia di muka bumi ini.

3. Tahsiniyah

Tahapan terakhir dari maqashid syariah ialah tahsiniyyat yang berarti dimana seseorang telah dapat memenuhi kebutuhan dasarnya. Meskipun tahsiniyyat tidak menambah efisiensi, efektivitas serta nilai tambah bagi aktivitas manusia, akan tetapi tidak ada salahnya apabila tahsiniyah dapat terpenuhi.

Dari penjelasan diatas, dijelaskan bahwa kebutuhan tahsiniyyat apabila disamakan dengan kebutuhan dalam istilah ekonomis makan kebutuhan tahsiniyyat merupakan kebutuhan tersier, dimana fungsi dasarnya ialah hanya sebagai "pemanis" dalam suatu 
Novadina, et al/Jurnal Ekonomi Syariah Teori dan Terapan Vol. 6 No. 3 Maret 2019: 510-524; MANAJEMEN MASJID NAMIRA LAMONGAN SERTA DAMPAKNYA TERHADAP JAMAAH MENURUT MAQASHID SYARIAH

maqashid syariah. Meskipun dengan tercapainya kebutuhan tahsiniyyat hal tersebut tidak akan menambah dari segi efisiensi, efektivitas dan juga nilai tambah bagi kegiatan manusia salam menjalani kehidupannya.

Dari uraian yang telah dijelaskan diatas dapat diketahui bahwasanya kita sebagai seorang muslim baiknya menerapkan nilai-nilai maqashid syariah dalam kehidupan kita sehari-hari, karena hal tersebut akan menyebabkan teraturnya hidup kita di muka bumi ini serta maqashid syariah akan menuntun kita lebih dekat dalam mencapai keridhaan Allah. Dan juga dengan adanya maqashid syariah kita juga dapat lebih menghargai agama kita, jiwa kita, akal kita, keturunan kita serta harta kita hal tersebut disebabkan karena kita tidak hanya memandang hal-hal tersebut sebagai materi tetapi juga sebagi pelengkap dari diri kita untuk menjalani kehidupan di bumi Allah ini.

Seperti yang kita ketahui sebelumnya bahwa tujuan maqashid syariah merupakan suatu bentuk perlindungan yang diberikan Allah kepada hambanya, baik untuk melindungi agamanya, untuk melindungi jiwanya, untuk melindungi akalnya, untuk melindungi keturunannya kemudian untuk melindungi harta bendanya kemudian dari penjagaan tersebut aka lahirlah kemaslahatan yang didamba-dambakan oleh para manusia.

Pemenuhan kebutuhan dharuriyyah, hajiyyah dan tahsiniyyah juga merupakan salah satu upaya dalam pemenuhan kemaslahatan umat. Karena memang itulah tujuan awal hukum Islam yakni unuk memelihara dan melestarikan kebutuhan manusia dalam semua peringkat baik kebutuhan dharuriyyah, hajjiyah dan tahsiniyah.

Shidia (2011:227-229) menyatakan sebagaimana yang dijelaskan oleh Fathurrahman Djamil, berikut ini akan diuraikan secara terperinci pokok-pokok permasalahan dengan masing-masing peringkat dalam maqashid syariah.

Penjelasan dibawah ini bertolok ukur dari kelima pokok kemaslahatan yakni agama, jiwa, akal, keturunan, dan harta, kemudian dilihat berdasar tingkat kepentingannya dalam maqashid syariah. a. Memelihara agama (hifz al-din)

Memelihara agama berdasarkan tingkat maqashid syariah dapat dibedakan menjadi tiga peringkat

1. Memelihara agama dalam tingkat dharuriyyat (pokok), yaitu dengan cara melaksanakan kewajiban agama seperti melaksanakan sholat fardhu di awal waktu. Apabila tidak dilakasanakan dengan baik, maka keutuhan agama akan goyah.

2. Memelihara dalam tingkatan hajiyyah, yakni dengan apabila kita dalam suatu perjalanan, kemudian sudah masuk waktu untuk melaksanakan sholat maka agar menghindari kesulitan baiknya sholatnya di jama' dan qashar. 
Novadina, et al/Jurnal Ekonomi Syariah Teori dan Terapan Vol. 6 No. 3 Maret 2019: 510-524;

MANAJEMEN MASJID NAMIRA LAMONGAN SERTA DAMPAKNYA TERHADAP JAMAAH MENURUT MAQASHID SYARIAH

3. Memelihara dalam tingkatan tahsiniyyah, yaitu dengan mengikuti petunjuk agama serta melaksanakan kewajiban kepada Allah akan tetapi tetap menjunjung tinggi martabat manusia. Contohnya ialah dengan menggunakan pakaian yang menutup aurat pada saat melaksanakan kewajiban sholat.

b. Memelihara jiwa (hifz an-nafs)

Memelihara jiwa berdasarkan peringkat kepentingannya dapat dibedakan menjadi tiga peringkat:

1. Memelihara jiwa dalam tingkatan dharuriyyat ialah dengan cara memenuhi kebutuhan primer agar hidup sentosa. Apabila kebutuhan primer ini tidak terpenuhi maka akan mengakibatkan tidak terancamnya keberlangsungan manusia.

2. Memelihara jiwa dalam tahapan hajiyyat ialah dengan cara menikmati makanan dan minuman yang lezat. Akan tetapi apabila tidak terpenuhi maka tidak akan mengancam eksistensi manusia.

3. Memelihara jiwa dalam tahapan tahsiniyyat ialah dengan cara menggunakan tata cara dalam makan dan minum. Apabila hal tersebut tidak dilakukan maka sebenarnya tidak mempersulit hajat hidup manusia, akan tetapi akan membuat manusia tersebut tidaklah beradab.

c. Memelihara akal (hifz al-aql)
Memelihara akal dilihat dari segi kepentingannya dapat dibedakan menjadi tiga tingkatan:

1. Memelihara akal dalam tingkatan dharuriyyat ialah dengan cara tidak mengonsumsi minuman keras yang haram hukumnya sehingga dapat menjaga kesadaran akal.

2. Memelihara akal dalam tingkatan hajiyyat ialah dengan cara menuntut ilmu setinggi mungkin sehingga dapat mempermudah seseorang dalam mencari pekerjaan dimasa yang akan datang.

3. Memelihara akal dalam tingkatan tahsiniyyat dengan cara menyibukkan diri dengan kegiatan yang bermanfaat serta dapat menambah produktifitas.

d. Memelihara keturunan (hifz an-nasl) Memelihara keturunan dilihat dari segi kebutuhannya dapat dibedakan menjadi tiga tingkatan:

1. Memelihara keturunan dalam tingkatan dharuriyyat ialah dengan cara melaksanakan pernikahan bagi yang telah mampu. Hal tersebut agar terhindar adanya perbuatan zina diluar nikah yang tidaklah bertanggung jawab.

2. Memelihara keturunan dalam tingkatan hajiyyat ialah dengan cara menyebutkan mahar pada saat ijab kabul pernikahan.

3. Memelihara keturunan dalam tingkat tahsiniyyat dengan cara 
Novadina, et al/Jurnal Ekonomi Syariah Teori dan Terapan Vol. 6 No. 3 Maret 2019: 510-524;

MANAJEMEN MASJID NAMIRA LAMONGAN SERTA DAMPAKNYA TERHADAP JAMAAH MENURUT MAQASHID SYARIAH

disyariatkannya khitbah sebelum melakukan pernikahan.

e. Memelihara harta (hifz an-mal)

Dilihat dari segi kepentingannya, memelihara harta dapat dibedakan menjadi tiga tingkatan antara lain:

1. Memelihara harta dalam tingkatan dharuriyyat dengan cara dilarangnya mengambil hak orang lain secara paksa dan tidak sesuai dengan syariat yang berlaku.

2. Memelihara harta dalam tingkatan hajiyyat dengan cara apabila melakukan transaksi yang mana produsen membutuhkan modal untuk memproduksi barang terlebih dahulu baiknya menggunakan akad salam, agar mempermudah produsen dalam memproduksi barang pesanan.

3. Memelihara harta dalam tingkatan tahsiniyyat dengan cara berhatihati dalam setiap transaksi yang dilakukan, hal tersebut dilakukan agara terhindar dari penipuan yang dilakukan oleh pihak-pihak yang tidak bertanggung jawab.

Dalam hal-hal yang telah dijelaskan diatas bahwanya maqashid syariah mencakup berbagai macam aspek kehidupan dalam diri manusia masing-masing. Begitu Islam sangat mengatur kehidupan hambanya dengan sangat rinci, hal tersebut menggambarkan bagaimana allah sangat mengatur hamba-hambanya hingga ke aspek terinci kehidupan hambanya masingmasing. Baik dalam aspek hablu minallah dan juga aspek hablu minanaas. Dan bentuk kepedulian Allah ialah dengan mengatur maqashid syariah yang telah dipaparkan diatas tersebut.

\section{METODOLOGI PENELITIAN}

Penelitian ini membahas tentang bagaimana bentuk manajemen masjid Namira Lamongan yang nantinya dapat membawa kesejahteraan bagi jamaah masjid Namira Lamongan. Untuk mencapai tujuan tersebut, maka pendekatan yang digunakan dalam penelitian ini adalah pendekatan kualitatif. Hal ini karena untuk menjawab rumusan masalah yang telah dipaparkan sebelumnya. Metode yang digunakan dalam penelitian ini ialah dengan kualitatif deskriptif. Menurut Bungin (2014:68) kualitatif deskriptif yaitu suatu penelitian yang bertujuan menggambarkan, meringkaskan segala kondisi dan fenomena yang terjadi di masyarakat agar dapat diidentifikasi sebagai suatu gambaran tentang kondisi masyarakat tersebut. Maka berdasarkan penjelasan diatas, dapat disimpulkan bahwa penelitian ini bersifat sangat memusatkan diri pada suatu titik tertentu dalam suatu fenomena, sehingga penelitian ini menggunakan metode kualitatif deskriptif, sesuai dengan tujuan awal yakni untuk mendalami mengenai manajemen masjid Namira. Sumber dan jenis data dalam penelitian ini terdiri dari

1. Data primer

Sumber data dalam penelitian ini adalah sebagai berikut: Wawancara dengan Ketua Takmir Masjid Namira 
Novadina, et al/Jurnal Ekonomi Syariah Teori dan Terapan Vol. 6 No. 3 Maret 2019: 510-524; MANAJEMEN MASJID NAMIRA LAMONGAN SERTA DAMPAKNYA TERHADAP JAMAAH MENURUT MAQASHID SYARIAH

yang merupakan narasumber utamadalam wawancara ini, karena penulis menilai bahwa ketua takmir masjid Namira mengetahui segala seluk beluk operasional dalam masjid Namira, wawancara dengan perwakilan dari yayasan yang menaungi masjid Namira, kemudian wawancara dengan beberapa warga sekitar masjid Namira Lamongan .

Dari beberapa narasumber tersebut diharapkan peneliti mendapatkan informasi secara lengkap mengenai bagaimana manajemen masjid Namira serta penulis juga akan melakukan obeservasi lapangan agar mengetahui dampak dari manajemen masjid Namira terhadap kesejahteran jamaah menurut perspektif maqashid syariah.

2. Data Sekunder

Data yang mendukung penelitian, yang didapatkan secara tidak langsung dari suatu objek penelitian yang berupa arsip, laporan, dan dokumen yang relevan serta kajian pustaka yang berkaitan dengan penelitian. Data sekunder dalam penelitian ini diperoleh dari buku, jurnal, majalah, surat kabar, dan dokumen atau laporan kegiatan penelitian yang pernah dilakukan yang terkait dengan implementasi saldo nol rupiah dana infaq masjid Namira Lamongan atau yang sejenisnya.

Peneliti menggunakan triangulasi sumber dalam penelitian ini. Menurut Sugiyono (2014:125), triangulasi sumber adalah menguji kredibilitas data dilakukan dengan cara mengecek data dengan beberapa teknik.

Dengan menggunakan tiga macam teknik dalam menganalisis data kualitatif yang didapatkan di lapangan, penulis ingin mengatahui secara mendalam tentang bagaimana manajemen Masjid Namira Lamongan serta dampaknya bagi kesejahteraan jamaah dalam perspektif maqashid syariah kemudian memaparkannya kedalam tulisan narasi.

\section{HASIL DAN PEMBAHASAN}

Kesejahteraan merupakan dampak yang terjadi apabila maqashid syariah dipenuhi secara baik. Fauzia dan Riyadi (2014:44-45) menjelaskan para ulama sepakat bahwasanya setiap kali ada hukum syari'ah yang ditetapkan pastilah memiliki tujuan dan juga alasan yang jelas serta logis. Tujuannya tak lain ialah agar kemaslahatan umat manusia di muka bumi ini terjaga. Ibn Qayyim alJawziyyah dalam Jasser Audah juga menjelaskan bahwa syariah merupakan suatu bentuk perlindungan bagi setiap manusia di dunia ini maupun di akhirat kelak. Syariah merupakan suatu bentuk keutuhan dari keadilan, kedamaian, kebijakan, dan juga kebaikan. Oleh karenanya apabila suatu tujuan yang baik akan tetapi jalan yang dilalui harus melalui sesuatu yang malah sebaliknya, maka hal tersebut tidak dapat dikatakan sebagai syari'ah.

Karena jelas sekali bahwa Allahselalu meminta hambanya agar 
Novadina, et al/Jurnal Ekonomi Syariah Teori dan Terapan Vol. 6 No. 3 Maret 2019: 510-524; MANAJEMEN MASJID NAMIRA LAMONGAN SERTA DAMPAKNYA TERHADAP JAMAAH MENURUT MAQASHID SYARIAH

melaksanakan kebajikan yang dapat membawa kemaslahatan bagi bersama. Apabila terdapat hukum yang tidak membawa kemaslahatan jelas bahwa sumber hukum tersebut bukanlah dari Allah. akan tetapi, terdapat beberapa hukum yang memang tidak murni dari Allah, melainkan hukum yang berasal dari hasil ijtihad atau takwil manusia yang ilmunya hanyalah sebatas dan juga tidak semuanya sesuai dengan konteks yang lainnya. Berdasarkan definisi diatas, maka dapat disimpulkan bahwa kita dapat menarik benang merah antara maqashid syariah dengan kemaslahatan. Allah menetapkan suatu hukum tidak lebih ialah untuk menumbuhkan kemaslahatan bagi hambanya sendiri, baik di dunia maupun di akhirat. Maqashid syariah juga bertujuan untuk memberikan petunjuk kepada hambaNya, agar tidak memilih jalan yang sesat tanpa arah tujuan dan juga agar hidup manusia lebih teratur karena hidup dengan aturan yang telah ditetapkan oleh Allah. Maqashid syariah juga dapat digunakan sebagai tolok ukur apakah seseorang telah mencapai suatu kemaslahatan, ataukah justru belum mencapai titik kemaslahatan tersebut.

Pada penelitian ini peneliti menggunakan indikator maqashid syariah yang terdiri dari lima poin, yakni: menjaga agama, menjaga jiwa, menjaga akal, menjaga keturunan dan menjaga harta. Dengan menggunakan indikator tersebut peneliti ingin melihat apakah program yang diselenggarakan oleh Masjid Namira telah memenuhi poin-poin yang telah penulis jabarkan sebelumnya.

1. Kajian Rutin

Berdasarkan informasi yang didapatkan peneliti dari wawancara dengan beberapa narasumber, kajian rutin yang diselenggarakan oleh Masjid Namira ada kajian umum yang diselenggarakan setiap Jum'at minggu pertama, kemudian kajian al-hadits yang diselenggarakan pada Jum'at minggu kedua, kajian tafsir yang diselenggarakan pada Jum'at minggu ketiga, kajian tauhid yang diselenggarakan pada Jum'at minggu keempat, kemudian Masjid Namira juga menyelenggarakan kajian sirah nabawiyyah, kajian fiqih, kajian khusus muslimah serta kajian tematik yang diselenggarakan setiap Ahad minggu kedua dan Ahad minggu keempat pada pukul 15.30.Sasaran dari kajian umum ini ialah masyarakat yang bertempat tinggal dekat dengan Masjid Namira.

2. Buka Puasa Bersama Senin-Kamis

Berdasarkan informasi yang didapatkan peneliti dari wawancara dengan beberapa narasumber, buka puasa bersama yang dilaksanakan setiap minggunya pada hari senin dan juga kamis. Prosedurnya ialah dengan membagikan voucher kepada para jamaah yang sedang melaksanakan puasa sunnah Senin Kamis. Sasaran dari program buka puasa bersama ini ialah masyarakat yang tinggal di sekitar Masjid Namira 
Novadina, et al/Jurnal Ekonomi Syariah Teori dan Terapan Vol. 6 No. 3 Maret 2019: 510-524;

MANAJEMEN MASJID NAMIRA LAMONGAN SERTA DAMPAKNYA TERHADAP JAMAAH MENURUT MAQASHID SYARIAH

3. Aku Cinta Masjid

Berdasarkan informasi yang didapatkan peneliti dari wawancara dengan beberapa narasumber, program "AkU Cinta Masjid" ini ditujukan bagi anak-anak usia SD hingga SMP. Setiap masuk waktu sholat dan lima menit sebelum waktu sholat anak harus scan fingerprint di tempat yang telah disediakan, kemudian apabila anak absen pada saat solat subuh maka anak akan mendapatkan dua poin, kemudian pada sholat dhuhur, ashar, maghrib, isya, maka anak akan mendapatkan satu poin, setiap akhir bulan poin yang terkumpul akan direkap oleh takmir. Prosedur pendaftarannya ialah pertama-tama anak yang ingin ikut serta mendaftarkan diri di bagian takmir masjid, kemudian setiap lima menit sebelum solat berjamaah dilakukan anak-anak akan melakukan scan fingerprint di tempat yang telah disedikan oleh pihak masjid untuk merekap data si anak. Sasaran dari program "Aku Cinta Masjid" ini ialah anak-anak yang berusia SD hingga SMP yang tinggal di sekitar Masjid Namira.

4. Waroeng Subuh
Berdasarkan informasi yang didapatkan peneliti dari wawancara dengan beberapa narasumber, program waroeng subuh ini merupakan kegiatan rutin yang dilakukan pada hari Minggu pagi. Jadi Minggu dini hari sekitar jam 03.00 pagi takmir masjid memfasilitasi jamaah untuk sholat tahajud berjamaah kemudian dilanjutkan dengan sholat subuh berjamaah setelah sholat subuh berjamaah takmir mengadakan kajian keagaaman hingga pukul 06.00 setelahnya masjid akan memberikan sarapan gratis bagi jamaah yang telah hadir. menurut salah satu pengunjung yang peneliti wawancarai, mengatakan memang dia telah meniatkan diri untuk melaksanakan sholat tahajud di Masjid Namira dan juga sholat shubuh berjamaah sekaligus mendengarkan kajian setelah sholat subuh, informan juga mendapatkan sarapan gratis yang telah disediakan oleh masjid setelahnya. Sasaran dari program ini ialah masyarakat yang tinggal di sekitar Masjid Namira.

Berikut adalah ringkasan dari hasil penelitian yang telah dibahas sebelumnya, tersajikan dalam Tabel 1: 
Novadina, et al/Jurnal Ekonomi Syariah Teori dan Terapan Vol. 6 No. 3 Maret 2019: 511-525;

MANAJEMEN MASJID NAMIRA LAMONGAN SERTA DAMPAKNYA TERHADAP JAMAAH MENURUT MAQASHID SYARIAH

Tabel 1.

Hasil Penelitian

\begin{tabular}{|c|c|}
\hline IndikatorMaqashidSyariah & Penjelasan \\
\hline Menjaga agama & $\begin{array}{l}\text { Jika dilihat dari indicator menjaga agama, Masjid Namira telah memenuhinya melalui } \\
\text { program kerja yang telahdilaksanakan, contohnyasaja: } \\
\text { 1. Melalui program kajian rutin, banyak sekali jamaah yang tertarik untuk } \\
\text { mendatangi Masjid Namira, hal tersebut dikarenakan Masjid Namira selalu } \\
\text { mengadakan kajian dengan tema yang berbeda tiap minggunya dan juga } \\
\text { penceramah yang mana tak hanya dari local saja, melainkan juga Masjid } \\
\text { Namira mengundang penceramah nasional, yang mana hal tersebut tentu } \\
\text { saja meningkatkan animo masyarakat sekitar untuk dating ke Masjid Namira } \\
\text { untuk mendengarkan kajian yang dapat menambah tingkat keimanan dan } \\
\text { dapat menambah tingkat religiusitas para jamaah itu sendiri. } \\
\text { 2. Tidak hanya jamaah yang berusia dewasa, melalui program Aku Cinta Masjid, } \\
\text { Masjid Namira dapat menarik minat anak - anak usia SD hingga SMP untuk rajin } \\
\text { mendatangi Masjid Namira untuk melaksan akan sholat berjamaah di Masjid } \\
\text { Namira. Sehingga membuat Masjid Namira kian ramai dengan banyaknya } \\
\text { jamaah dari berbagai kalangan usia. }\end{array}$ \\
\hline Menjaga jiwa & $\begin{array}{l}\text { Jikadilihatdari indicator menjaga jiwa, Masjid Namira telah memenuhinya melalui } \\
\text { program kerja yang telah dilaksanakan, contohnya saja: } \\
\text { 1. Melalui program buka puasa Senin Kamis, Masjid Namira telah memudahkan } \\
\text { aksesibilitas warga yang mana ingin segera melaksanakan sholat maghrib } \\
\text { berjamaah setelah membatalkan puasanya. } \\
\text { 2. Melalui program waroeng subuh, Masjid Namira telah menyediakan sarapan } \\
\text { gratis bagi para jamaah yang telah melaksanakan ibadah semalam suntuk. }\end{array}$ \\
\hline Menjaga akal & $\begin{array}{l}\text { Jika dilihat dari indicator menjaga akal, Masjid Namira telah memenuhinya melalui } \\
\text { program kerja yang telah dilaksanakan, contohnya saja: } \\
\text { 1. Melalui program kajian rutin, para jamaah diberikan pengetahuan tambahan, } \\
\text { hal tersebut karena Masjid Namira mengundang penceramah dari berbagai } \\
\text { kalangan, jadi para jamaah mendapatkan tambahan ilmu yang bermanfaat. } \\
\text { 2. Melalui program AkuCinta Masjid, Masjid Namira telah memfasilitasi dengan } \\
\text { mengadakan pendidikan taman bacaan Al-Qur'an bagi anak berusia SD } \\
\text { untuk belajar membaca Al-Qur'an bersama-sama }\end{array}$ \\
\hline Menjaga keturunan & $\begin{array}{l}\text { Jika dlihat dari indicator menjaga keturunan, Masjid Namira telah memenuhinya melalui } \\
\text { program kerja yang telah dilaksanakan, contohnya saja: } \\
\text { 1. Melalui program Aku Cinta Masjid, anak-anak usia dini diajak untuk rajin dating } \\
\text { ke masjid, apabila semakin rajin anak tersebut, maka semakin besar reward } \\
\text { yang akan didapatkan sang anak. }\end{array}$ \\
\hline Menjaga harta & $\begin{array}{l}\text { Jika dilihat dari indicator menjaga harta, Masjid Namira telah memenuhinya melalui } \\
\text { program kerja yang telah dilaksanakan, contohnya saja: } \\
\text { 1. Dengan adanya program kajian rutin yang diadakan oleh Masjid Namira, } \\
\text { maka akan mengundang banyak sekali para jamaah yang hadir, dengan } \\
\text { banyak pengunjung yang hadir ke Masjid Namira maka akan menambah } \\
\text { penghasilan warga sekitar yang berprofesi sebagai pedagang yang berada di } \\
\text { sekitaran Masjid Namira. } \\
\text { 2. Melalui program Aku Cinta Masjid, Masjid Namira telah memberikan reward } \\
\text { berupa sejumlah uang bagi anak yang telah mencapai poin tertentu, yang } \\
\text { mana kedepannya uang tersebut dapat digunakan untuk ditabung oleh sang } \\
\text { anak untuk kebutuhannya di kemudian hari. }\end{array}$ \\
\hline
\end{tabular}

\section{SIMPULAN}

Berdasarkan

pembahasan

sebelumnya, kesimpulan yang dapat

diambil dari hasil penelitian ini ialah:

1. Bentuk implementasi dari saldo nol rupiah yang dilaksanakan oleh masjid Namira ialah dengan menyusun beberapa program kerja yang mana sasaran utamanya dari keseluruhan program ialah masyarakat sekitar.

Kemudian sumber pendanaan

utamanya ialah dari infaq yang didapat secara sukarela dari para jamaah, akan tetapi apabila dana infaq tersebut tidak menutupi kebutuhan operasional yang dibutuhkan maka kekurangannya akan ditanggung oleh pihak yayasan 
Novadina, et al/Jurnal Ekonomi Syariah Teori dan Terapan Vol. 6 No. 3 Maret 2019: 510-524;

MANAJEMEN MASJID NAMIRA LAMONGAN SERTA DAMPAKNYA TERHADAP JAMAAH MENURUT MAQASHID SYARIAH

keluarga yang menaungi masjid Namira.

2. Temuan yang didapatkan dari penelitian ini ialah bahwa seringnya setiap bulan dana infaq yang terkumpul dari para jamaah selalu tidak mencukupi untuk membayar dana operasional masjid yang kebutuhannya sangat besar, oleh karena itulah kekurangan dana tersebut ditutupi oleh yayasan keluarga yang menaungi masjid Namira.

3. Dampak maslahah dari program kerja yang disusun oleh pengurus takmir telah tercapai karena telah memenuhi poin-poin yang ada di maqashid syariah yaitu, agama (addin), jiwa (an-nafs), akal (al-aql), keturunan (an-nasl), dan harta (almal).

\section{DAFTAR PUSTAKA}

Al-Qur'an danTerjemahannya. 2013. Departemen Agama Republik Indonesia. Arifin, Gus. 2016. Keutamaan Zakat Infak, Sedekah. Jakarta: PT. Elex Media Komputindo.
Bungin, Burhan. 2005. Metodologi Penelitian Kualitatif: Komunikasi, Ekonomi, dan Kebijakan Publik serta IImu-IImu Sosial Lainnya. Jakarta: Kencana.

Fauzia, Ika Yunia Dan Abdul Kadir Riyadi. 2014. Prinsip Dasar Ekonomi Dasar Islam Perspektif Maqashid Al Syariah. Jakarta: Kencana.

Hafidhuddin, Didin. 2007. Agar Harta Berkah Dan Bertambah. Jakarta: Gema Insani Press.

ICMI Orsat Cempaka Putih, Fokkus Babinrohis Pusat. 2004. Pedoman Manajemen Masjid. Jakarta: Yayasan Kado Anak Yatim.

Sholihin, Ahmad Ifham. (2010). Buku Pintar Ekonomi Syariah. Jakarta: Pt. Gramedia Pustaka Utama.

Shidiq, Sapiuddin. 2011. Ushul Fiqh. Jakarta: Kencana.

Yin, Robert K, 2003. StudiKasus: Desain Dan Metode. Jakarta: Raja GrafindoPersada.

Sumber Berasal dari Internet: bps.go.id: September: 2018

simas.kemenag.go.id: Februari: 2018 